Funding: See page 95

Peer review: This article has been subject to a double blind peer review process

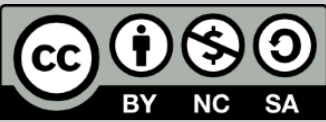

C Copyright: The Authors. This article is issued under the terms of the Creative Commons Attribution NonCommercial Share Alike License, which permits use and redistribution of the work provided that the original author and source are credited, the work is not used for commercial purposes and that any derivative works are made available under the same license terms.

\section{Defining 'Movement' in Global History: The Early Modern Iberian World in a Global Frame $\left(16^{\text {th }}-18^{\text {th }}\right.$ centuries)}

\author{
Desiree Arbo* \\ Department of Classics and Ancient History, University of Warwick \\ *Correspondence: D.Arbo@warwick.ac.uk
}

\begin{abstract}
On 9 June 2017, scholars from a range of disciplines across the United Kingdom and Spain met at the University of Warwick to discuss the ways in which taking a global perspective can enrich research on early modern Iberia and colonial Spanish America. Coming at a time when Spanish exceptionalism is being increasingly challenged but the Americas are still being side-lined in the writing of global history, the presenters addressed gaps in current historiography and challenged Eurocentric narratives of early modern history which have predominated since the Enlightenment. The final roundtable called for definition in the language of movement in global history and concluded that we need to rethink global history as a project that began in the sixteenth century with conceptions of an Iberian or Catholic globe, an orbe hispano.
\end{abstract}

Keywords: global; early modern; Iberia; empire; exchanges; migration; circulation

Spain, Portugal and their former colonies in America are by no means political powers in the globalised world of the twenty-first century. This was not the case between the sixteenth and eighteenth centuries. The first America was not that of the thirteen English colonies in North America, but the one reached by the Spaniards (Brading, 1991). The first great overseas expeditions, and the first global histories, were written in the Iberian world.

Since the late eighteenth century, historians have spent much time pondering the reasons why Spain and Portugal declined in influence on the world stage, or why they (and Latin America) failed to enter a modern age along with the rest of Europe. The French Enlightenment and the writers of the Encyclopédie proposed that the Iberian states contributed nothing to 'progress' - that in fact, they had historically impeded progress. In the last five decades this notion of 'Spanish 
exceptionalism' has been demystified: The rise and decline of the Spanish and Portuguese empires are now seen in terms of historical contingencies, rather than as the result of some intrinsic virtues or flaws (Elliott, 2017). However, a disconnection between global history and what is called 'Latin American history' remains: 'too much global history and too much Latin American history has situated Latin America as marginalized, passive, or a victim' (Brown, 2015: 366). This is particularly true of the post-1800 period but applies also to the early modern period, where Anglophone scholarship still thinks of the Iberian world in terms of 'empires'. The most recent Cambridge World History for instance, includes chapters on the Iberian empires and the indigenous American empires (Bentley et al., 2015). While the history of empire is undoubtedly important, there are other global stories to be told. The workshop participants contributed in different ways towards defining a language of movement in global history, which can be broadly defined as a field that seeks to transcend the writing of history based on single nations and regions, primarily through the two dominant approaches of connections and comparisons (O'Brien, 2006).

In the opening paper, Elizabeth Evenden-Kenyon (Brunel University) presented a history of exchanges of Arthurian legends between England, Spain, and Portugal in the sixteenth and early seventeenth centuries. Her paper 'Early Modern printers, exiles, and exchanges between England and Iberia' stressed the role of the translator and the position of exiles within networks in these exchanges. Anthony Munday (1553-1633) emerged as key figure in English responses to the continental versions of Arthurian romances through his translations of the Amadis of Gaul and the Palmerin of England, which appeared in several English editions starting in 1588. . In the Iberian world, the romances were common ground for a discourse of nobility. In England, Evenden-Kenyon argued that the Iberian romances were not merely popular entertainment, but also offered a 'refashioning' of English history, one that crossed confessional divides. Amidst the heightened tensions between Spain and England in the post-Reformation world of the 1580s, and with England's continued friendship with Portugal, the romances could be seen not only as nostalgic views of Anglo-Iberian medieval relations but also as texts that intertwined European Catholicism with English history. A recent monograph stressed similarities between Iberian interpretations of Arthur (Hook, 2015). In contrast, Evenden-Kenyon showed that the different uses of Arthuriana in each context ultimately reveal a concern in the 1580s and beyond with how history ought to be written, when chronicles ought to be considered fable or history. She also revealed the potential for English readers to view Portuguese Catholicism differently to Spanish Catholicism, through the lens of their uses of Arthuriana. 
Marina Bezzi (University College London) picked up the theme of 'history of historiography' in her analysis of the works of travel writers Richard Hakluyt and Lancelot Voisin de La Popelinière. In the 1580s Hakluyt and La Popelinière mobilised Iberian authorities to forge pro-colonial discourses, drawing from a body of Spanish and Portuguese colonial knowledge. In his Diverse Voyages (1589), Hakluyt invented England's role in maritime expansion by recording a conversation with the Portuguese ambassador in London Dom António de Castilho about a Portuguese voyage to the Northwest Passage in 1574. In his Trois Mondes (1582) La Popelinière argued that the French should learn from 'Spanish mistakes' during their conquests, for which he also relied on Portuguese chronicles. Furthermore, La Popelinière's L'Histoire des Histoires (1599) outlined four stages in the writing of history, from the non-verbal kind of the Tupi in Brazil to contemporary Europeans. The result was arguably the first global history of historiography. Thus, Bezzi showed that expanding geographical horizons prompted new ways of writing history, a conclusion which could be placed in fruitful dialogue with scholarship on the creation of knowledge after the encounter of Europeans with the New World (Pagden, 1982; Cañizares-Esguerra, 2001).

Moving on from the movement of texts to movement of people, Cecilia Tarruell (University of Oxford) presented some unexpected ways in which Muslims, Jews and Eastern Christians settled in sixteenth-century Spain and its overseas provinces. As is the case for most researchers on the early modern Iberian world, secondary scholarship is fragmented and not found in English. Tarruell synthesised Spanish and French findings, pointing out that confessional groups in exile have until now usually been studied in isolation, with some exceptions such as in cosmopolitanism Venice (Minchella, 2014). A range of reasons underlay the movement of Islamic people across the Mediterranean, including people fleeing from civil wars and famine, slaves escaping their masters, merchants with previous contacts in Spain, and dethroned kings (Alonso Acero, 2006;

Ruiz Ibáñez and Pérez Tostado, 2015). A crucial element of Tarruell's argument was the self-presentation of the Habsburg kings as the universal protector of all Catholics in the world. She explained that the petitions presented to the Spanish authorities by converts from Islamic lands specifically pointed out their desire to live as Catholics, a plea which the kings of Spain could not refuse without contradicting their universal claims. The voluntary movement of these people thus challenges many traditional assumptions about early modern Spain, which is traditionally seen as the land of expulsion and forced conversion of religious minorities. 
Pedro Svriz Wucherer (Universidad Pablo de Olavide) followed with another global microhistory, presenting a case study of the Guarani militias in colonial Paraguay. His paper engaged with debates of the 'Military Revolution', which are usually confined to early modern Europe. Traditionally, the creation of standing armies were held to be part of the process of European state-building. In contrast, a revisionist view now emphasises a 'military devolution' where European states relied on private contractors to recruit and supply armies and navies (Parker, 1988; Parrott, 2012). Svriz Wucherer follows the revisionist line but questions the Eurocentric narrative of the 'rise of the West' through military expansion. He demonstrated that military prerogatives devolved into the hands of Jesuits and Guarani Indians in seventeenth-century Paraguay, when colonial authorities proved unable to defend cities and Jesuit reductions from hostile indigenous tribes and the raiding bandeirantes of San Paulo. The mobilisation of troops, at this local level, depended on negotiations between Jesuits, Guarani Indians, and the colonial cities. In Paraguay, as also in colonial Peru, the use of violence was a collaborative affair rather than a centralised enterprise directed from Madrid with standing armies.

The dynamic between centralisation and circulation in global history was a theme of the two final papers. Desiree Arbo (University of Warwick) examined the role of the Jesuit order in the trans-Atlantic book trade and the formation of libraries. These subjects have not been studied together with any sustained attention in Spanish American contexts. As a network that operated alongside the official imperial networks, the Jesuits developed an efficient system of acquiring and transporting printed books to support their missionary and educational projects in the Americas (García Galán, 1995; Martínez-Serna, 2009). Arbo argued that conditions of the European book market and the curriculum outlined in the Ratio Studiorum dictated to an extent the kinds of books sent from Europe, but the demand for books and their circulation in Spanish America varied according to local needs.

In the final paper of the day, Rocio Moreno Cabanillas (Universidad Pablo de Olavide) surveyed the reforms of postal services in the eighteenth century. Circulation of information has been shown to be key to establishing global connections (Conrad, 2016). Moreno Cabanillas took a comparative approach in her presentation of reforms of postal systems in the British, Portuguese and Spanish empires. She emphasised the contrast between imperial aims and the difficulties in implementing the reforms due to the enormous distances. While the postal systems were perceived as essential to have more efficient control of colonial possessions, the dissemination of information depended on negotiations with local officials. 
Moreno Cabanillas raised a methodological concern that resonated with all the workshop participants: the need to consult several archives. This is nothing new for global historians. What is less often observed is that archival materials tend to present different stories. Documents in the Archivo General de Indias (AGI), for example, reveal Bourbon attempts to control the monopoly of the postal system. Similarly, the Archivum Historicum Societatis lesu (ARSI) holds correspondence between Rome and the Jesuit provinces, producing the impression that much of Jesuit activity was regulated by Rome. Many decisions and much of the paperwork, however, stayed at local levels. Thus, American archives tend to suggest a narrative that is about negotiation rather than centralisation. It is only by comparing material from both central European archives and overseas archives that we can better understand the relationship between centralisation and circulation.

Led by Mark Thurner (ILAS, University of London) and Julia McClure (University of Warwick), the final roundtable addressed ways to define a language of movement that could adequately be applied in the study of the early modern Iberian world. The language we use as historians is highly problematic, which is made more acute by differences between academic traditions. Thus, the 'Spanish Empire' of Anglophone scholarship has no equivalent in Spanish academic circles, where the term monarquia hispánica is preferred. However, people of the early modern period did not think of themselves as living in a 'Spanish Empire'. Rather, they perceived themselves as subjects of several Iberian, European, and American kingdoms under the Habsburgs. J.H. Elliott's seminal 1992 article on composite monarchies already reflected a growing scholarly awareness of the polycentric nature of the lberian world. Since then Elliott's model has been refined into one that stresses interconnectedness and questions the model of centre and subordinate peripheries (Elliott, 1992). A growing historiography also addresses the fates of the Spanish and Portuguese monarchies in conjunction, using the term monarquías ibéricas - 'Iberian monarchies' (Cardim et al., 2012). This trend was echoed in the structure of the workshop, which ultimately called for a consideration of the polycentric and global nature of this 'Iberian world'.

'Migration' is another problematic term, because it presupposes that people move from one region to another in search of better living conditions. 'Circulation' would be more apt to describe the winding and multi-directional movement of people in the early modern period. While 'circulation' is well-accepted in French circles, Anglophone readers regard it with certain suspicion as lacking definition, precisely because we still lack a consensus of how to conceptualise movement in global history: Is it about following objects and peoples from place to place, or is global 
history a methodological frame of mind, one that is aware of connections between micro and macro levels? The material turn in history has resulted in fruitful enquiry about these questions (Gerritsen and Riello, 2015), but they become harder to answer regarding the mobility of people. A focus on tracing the journeys of travellers to establish global connections is not enough: the historian must also consider questions of subjectivity, self-fashioning and local contexts. Thus, 'the close study of a global life drags us back necessarily to a deep, local history' (Ghobrial, 2013: 59). Clearly, the potential for microhistorical approaches to global history has yet to be fully exploited (Trivellato, 2011; Ginzburg, 2015).

Overall, the roundtable agreed that future research requires interdisciplinarity, collaboration with ongoing projects in different academic environments, consulting archives in several locations, and conducting particularly rigorous examination of micro-historical phenomena before working outwards with global themes and connections. By taking a global perspective nations begin to fade in the background, which is perhaps its greatest attraction for historians. National identities certainly existed in early modern Europe (Hirschi, 2011) but we need to be careful of taking 'nations' as the objects of study, lest we create artificial boundaries that did not exist in that time. 'Transnationalism' does not solve the problem and cannot adequately be applied to Spanish America before the nineteenth century: it suggests a teleological narrative where nations already existed and were just waiting to become independent from Spain after 1808 (CañizaresEsguerra, 2009). This is especially problematic in colonial histories of Latin American countries, which continue to be written as national histories. Instead of creating anachronistic borders, the papers of this workshop presented an argument for global connections through two main avenues: by studying 'linking nodes' such as networks and paper trails, and by rethinking global history as a project that began in the sixteenth century with conceptions of an Iberian or Catholic globe, an orbe hispano.

\section{Acknowledgements}

The workshop organiser (Desiree Arbo, University of Warwick) would like to acknowledge the kind assistance of Sheilagh Holmes of the Early Modern/Eighteenth Century Studies Centre (History Department, University of Warwick), and the financial support of the Institute of Advanced Study, the Global History and Culture Centre, and the Early Modern/Eighteenth Century Studies Centre at the University of Warwick. 


\section{References}

Alonso Acero, B. (2006), Sultanes de Berbería en tierras de la cristiandad. Exilio musulmán, conversión y asimilación en la Monarquía hispánica (siglos xvi y xvii), Barcelona: Bellaterra.

Brading, D.A. (1991), The First America: The Spanish Monarchy, Creole Patriots and the Liberal State 1492-1867, Cambridge: Cambridge University Press.

Bentley, J.H., S. Subrahmanyam, M.E. Wiesner-Hanks (eds.) (2015), The Cambridge World History, Volume 6: The Construction of a Global World, 1400-1800 CE, Cambridge: Cambridge University Press.

Brown, M. (2015), 'The global history of Latin America', Journal of Global History, 10 (3), 365-386.

Cañizares-Esguerra, J. (2001), How to Write the History of the New World: Histories, Epistemologies, and Identities in the Eighteenth-Century Atlantic World, Stanford: Stanford University Press.

Cañizares-Esguerra, J. (2009) 'Entangled Histories: Borderland Historiographies in New Clothes?' The American Historical Review 112 (3), 787-99.

Cardim, P., T. Herzog, J.J. Ruiz Ibáñez and G. Sabatini (eds.) (2012), Polycentric Monarchies: How did Early Modern Spain and Portugal Achieve and Maintain a Global Hegemony? Eastbourne (Oregon): Sussex Academic Press.

Conrad, S. (2016), What is Global History?, Princeton: Princeton University Press.

Elliott, J.H. (1992) 'A Europe of Composite Monarchies', Past \& Present 137 (1), 48-71.

Elliott, J.H. (2017) 'The history of early modern Spain in retrospect', in K. Lynn and E.K. Rowe (eds). The early modern Hispanic world: transnational and interdisciplinary approaches, Cambridge: Cambridge University Press, pp. 341-361.

García Galán, A. (1995), El Oficio de Indias 1566-1767, Sevilla: Fundación Fondo de Cultura de Sevilla.

Gerritsen, A. and G. Riello (eds.) (2016), The global lives of things: the material culture of connections in the early modern world, London: Routledge. 
Ginzburg, C. (2015), 'Microhistory and world history', in J. Bentley, S. Subrahmanyam, and M. Wiesner-Hanks (eds.), The Cambridge World History Vol. 6, pp. 425-445.

Ghobrial, J-P. (2014), 'The Secret Life of Elias of Babylon and the Uses of Global Microhistory', Past \& Present, 222 (1), 51-93.

Hirschi, C. (2011), The Origins of Nationalism: An Alternative History from Ancient Rome to Early Modern Germany, Cambridge: Cambridge University Press.

Hook, D. (2015), The Arthur of the Iberians: The Arthurian Legends in the Spanish and Portuguese Worlds, Cardiff: University of Wales Press.

Martínez-Serna, J.G. (2009), 'Procurators and the Making of the Jesuits' Atlantic Network,' in B. Bailyn and P. L. Denault (eds)., Soundings in Atlantic history: latent structures and intellectual currents, 1500-1830, Cambridge, Mass.: Harvard University Press, pp. 181-210.

Minchella, G. (2014), Frontiere aperte: Musulmani, ebrei e cristiani nella Repubblica di Venezia (XVII secolo), Rome: Viella.

O'Brien, P. (2006) 'Historiographical Traditions and Modern Imperatives for the Restoration of Global History', Journal of Global History 1 (1), 3-39.

Pagden, A. (1984), The Fall of Natural Man: The American Indian and the Origins of Comparative Ethnology, Cambridge Iberian and Latin American Studies. Cambridge: Cambridge University Press.

Parker, G. (1988), The Military Revolution: Military Innovation and the Rise of the West, 1500-1800, Cambridge: Cambridge University Press.

Parrott, D. (2012) The Business of War: Military Enterprise and Military Revolution in Early Modern Europe, New York: Cambridge University Press.

Ruiz Ibáñez, J.J. and I. Pérez Tostado (2015) Los exiliados del Rey de España, Madrid: Fondo de Cultura Económica de España.

Trivellato, F. (2011), 'Is There a Future for Italian Microhistory in the Age of Global History?', California Italian Studies 2 (1).

\section{To cite this article:}

Arbo, D. (2017). The Early Modern Iberian World in a Global Frame $\left(16^{\text {th }}-18^{\text {th }}\right.$ centuries). Exchanges: The Warwick Research Journal, 5(1), 90-97. Retrieved from:

http://exchanges.warwick.ac.uk/index.php/exchanges/article/view/195 